Vol. 2, No. 2, December 2021

\title{
SPEKTA
}

Jurnal Pengabdian Kepada Masyarakat: Teknologi dan Aplikasi

Journal homepage :

http://journal2.uad.ac.id/index.php/spekta

\section{COCONUT SHELL BIOBRIQUETTES TRAINING TO THE COMMUNITY OF KARANG KEMIRI, BELITANG, OGAN KOMERING ULU TIMUR REGENCY, SOUTH SUMATERA}

\author{
Alieftiyani Paramita Gobel ${ }^{1, *}$, Yandriani ${ }^{1}$, Chairunnisa Van Gobel ${ }^{2}$ \\ ${ }^{1)}$ Department of Mining Engineering, Faculty of Engineering, Universitas Sriwijaya, Indonesia \\ ${ }^{2)}$ Department Civil Engineering, Faculty of Civil Engineering and Plannning, Universitas Islam Indonesia, Indonesia
}

\begin{tabular}{l}
\hline ARTICLE INFO \\
\hline \\
Recived : December, 2020 \\
Revised : March, 2021 \\
Accepted : June, 2021 \\
\hline
\end{tabular}

Keywords:

coconut shell;

biobriquettes;

community Service

\begin{abstract}
The utilization of technology becomes an indicator of the growth of a society that solves problems, needs, benefits in an effective, efficient and sustainable ways. One of the technologies utilized by the community to reduce the massive exploitation of non-renewable fossil energy is to reuse alternative energy. Biobriquette becomes alternative energy from biomass waste that is possibly used in daily activities. In response to this, the purposes of performing the Community Service Program (PPM) in Karang Kemiri Village, Belitang District are; to 1) provide counseling and assistance to the community in creating biobriquette from coconut shells, 2) apply biobriquette in the cooking process. The PPM implementation method includes 3 (three) stages, that is socialization, biobriquette production, and biobriquette application. Based on the results achieved as a whole, the local Community welcomed the Community Service Program as it provides them new knowledge and skills regarding biobriquette creation. The other result of this community service program is to apply biobriquette instead of firewood to cook for their daily cooking needs.
\end{abstract}

\section{INTRODUCTION}

The use of briquettes in Indonesia is still identically sourced from fossil fuels, particularly coal. Coal is a non-renewable fuel, while coal resources and reserves are currently running low. Based on the newest data, Indonesia's coal reserves reached 26.2 billion tons. With coal production of 461 million tons last year, the age of coal reserves is still 56 years as is assumed that there are no new reserves found and production

\footnotetext{
* Corresponding author.

E-mail address: alieftiyani@ft.unsri.ac.id

https://doi.org/10.12928/J.spekta.v2i2.3223
} 


\section{Vol. 2, No. 2, December 2021}

increases (Geological Agency of the Ministry of Energy and Mineral Resources (ESDM), 2018). Therefore, it is necessary to develop alternative energy-based technologies to meet people's daily needs to reduce their dependence on fossil fuels.

Among various kinds of alternative energy, one of the energies that can be used in daily activities is briquettes from biomass waste or known as biobriquettes. Biobriquettes are solid fuels that produce heat energy with calorie units in a certain time until the heat energy is lost marked by extinguishing the fire and turning it into ashes. However, the most commonly used biomass contains chemical compositions in the form of lignin (wood substance) and cellulose which can be used as active substances as carbonized fuel in biobriquettes. Biomass in the form of organic waste can be obtained from agricultural, plantation, and livestock activities. This service program, using organic waste, namely coconut shells. The coconut tree is one of the plantation commodities that has zero waste or waste-free properties. It indicates that the whole part of the coconut tree can be utilized. In terms of chemical composition, the coconut shell consists of $74.3 \% \mathrm{C}, 21.9 \% \mathrm{O}, 0.2 \% \mathrm{Si}, 1.4 \% \mathrm{~K}, 0.5 \% \mathrm{~S}, 1.7 \% \mathrm{P}$ making it an opportunity as fuel and source of activated carbon (Bledzki, Mamun and Volk, 2010).

The use of briquette fuel can reduce the handling of firewood and the use of fuel oil. The utilization of briquettes as fuel can save time and cost as it has a relatively high calorific value. The use of coconut shell directly is not recommended because it will cause thick smoke, therefore it is necessary to firstly carbonize it to remove the water or moisture and volatile contained in the coconut shell (Labania and Nismayanti, 2014). Witnessing the daily life of the people in Karang Kemiri hamlet, the majority of whom still use firewood for cooking, certainly has an impact on cooking utensils, health, and the environment. In terms of health, the smoke produced when cooking using firewood will interfere with the respiratory system and damage the skin layer of the face if continuously exposed to combustion fumes, while the burning smoke is not environmentally friendly. In addition, from an economic point of view, biobriquettes are still very affordable for raw materials and the manufacturing process, because in Karang Kemiri village there are still a lot of coconut plantations owned by the community.

The objectives of this service program are 1) to provide socialization to the community regarding the use of biomass into biobriquettes and calculation of initial capital, 2) to provide technical guidance on making biobriquettes from coconut shells at Karang Kemiri village vi, and 3) to apply biobriquettes for cooking. This activity needs to do to provide knowledge to the community about the use of biomass waste that can be used as biobriquettes and is easy to manufacture as well as health-friendly in terms of environment and economy.

Based on previous research, it was found that coconut shells have carbon elements of moderate quality which can be used as the main ingredient of biochar/biobriquettes (Lubis, 2011). Physically, the coconut shell is the hardest part containing a lot of silicate elements $(\mathrm{SiO} 2)$ as shown in Table 1.

Tabel 1. The testing of Chemical Elements in Coconut Shell (Rusdianto, 2011)

\begin{tabular}{lc}
\hline \multicolumn{1}{c}{ Composition } & $\begin{array}{c}\text { Percentage } \\
(\boldsymbol{\%})\end{array}$ \\
\hline Lignin & 29,40 \\
Pentosan & 27,70 \\
Cellulose & 26,60 \\
Water & 8,00 \\
\hline
\end{tabular}


Vol. 2, No. 2, December 2021

\begin{tabular}{lc}
\hline Extractive Solvent & 4,20 \\
Uronic Anhydrous & 3,50 \\
Ash & 0,60 \\
Nitrogen & 0,10 \\
\hline
\end{tabular}

The conversion of coconut shells into charcoal is carried out through a pyrolysis (heating) process. During the carbonization process, elements such as carbon will not burn out, while the elements hydrogen $(\mathrm{H})$ and oxygen $(\mathrm{O})$ will be exhausted due to chemical reactions. The changes in the composition and thermal properties of coconut shells into charcoal are shown in Table 2.

Tabel 2. Basic Characteristics of Coconut Shell and Charcoal (Muharyani et al., 2012)

\begin{tabular}{clcc}
\hline Substance & \multicolumn{1}{c}{ Component } & Unit & $\begin{array}{c}\text { Analysis } \\
\text { Result }\end{array}$ \\
\hline \multirow{5}{*}{ Coconut Shell } & Heating Value & $\mathrm{kal} / \mathrm{gr}$ & 4027,8 \\
& Water Content & $\%$ & 10,46 \\
& Ash Content & $\%$ & 3,58 \\
& Volatile Matter & $\%$ & 67,67 \\
& Carbon Content & $\%$ & 18,29 \\
& Heating Value & $\mathrm{kal} / \mathrm{gr}$ & 7427,6 \\
Coconut Shell After & Ash Content & $\%$ & 13,08 \\
Carbonization & Volatile Matter & $\%$ & 10,60 \\
& Carbon Content & $\%$ & 76,32 \\
\hline
\end{tabular}

The after-carbonized coconut shell will turn into charcoal producing a fairly high calorific value with a difference of $3399.8 \mathrm{cal} / \mathrm{gr}$ followed by a decrease in moisture content. Coconut shell charcoal has carbon elements that can be used as biobriquettes. The existence of a carbonization process in coconut shells makes coconut shell charcoal rich in carbon elements. Physically, good-quality coconut shells are old and dry. The alternative drying can be done by drying the coconut shells before use. Furthermore, the appearance of an old coconut shell is shown by the dark brown color of the shell as shown in Figure 1 (Budi, 2011).

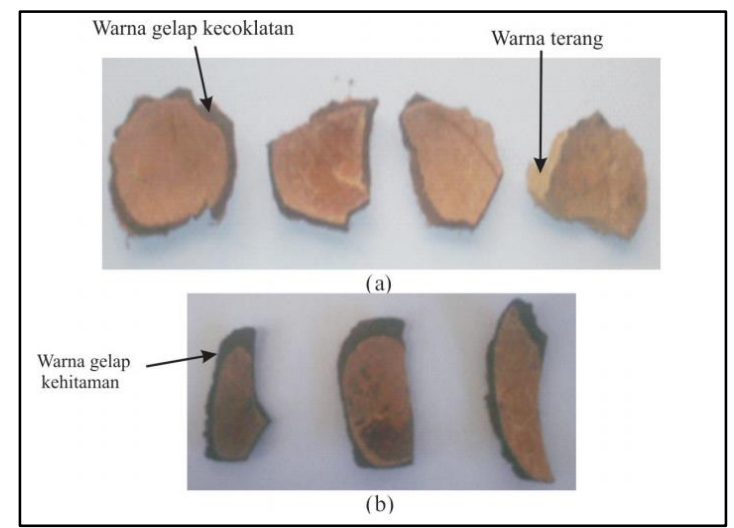

Figure 1. (a) Mature shells are pointed in dark brown; (b) The black shells that have been dried (in the sun) 
Vol. 2, No. 2, December 2021

In the brief terms, the process of making coconut shell biobriquettes is displayed out as follows (Lubis, 2011) :

1) Preparation of raw materials from impurities is such as sand and moss. It is by drying it under the sunlight to remove moisture content.

2) Composing (carbonization) uses a composting drum made of iron plate. This process aims to reduce the water content through heat energy.

3) The size reduction is done by pounding it using an iron mortar. After that, the sieving process is carried out to get a uniform size. Thus, the size is determined based on consumer needs.

4) The biobriquettes presswork is based on the fancied shape and dimensions (cylinder, cube, etc). The additional material used in the presswork process is an adhesive in the form of tapioca flour. Tapioca flour is cooked with water until the texture becomes like glue or paste. After that, the adhesive is mixed with coconut shell charcoal that has been sifted with a certain composition until the mixture becomes easily shaped, compressed, and pressed on the mold.

5) The last step is dying of molded biobriquettes in the sun or employing artificial drying using an oven. The recommended water content is between $10-20 \%$ by weight. The weight of biobriquettes varies from 20-100 grams. Therefore, it is necessary to dry the biobriquettes to reduce the water content in accordance to the applicable technical requirements as presented through the following Table 3.

Table 3 Coal briquette quality standard (Permen ESDM ,2006)

\begin{tabular}{clccccc}
\hline No. & Types of Coal Briquettes & $\begin{array}{c}\text { Moist } \\
\text { Water } \\
(\%)\end{array}$ & $\begin{array}{c}\text { Volatile } \\
\text { Matter } \\
(\%)\end{array}$ & $\begin{array}{c}\text { Caloric } \\
\text { Value } \\
(\text { Kkal/kg })\end{array}$ & $\begin{array}{c}\text { Sulphur } \\
\text { Total } \\
(\%)\end{array}$ & $\begin{array}{c}\text { Breaking } \\
\text { Load } \\
\left(\mathrm{Kg} / \mathrm{cm}^{2}\right)\end{array}$ \\
\hline $\begin{array}{l}\text { Light Coal Type } \\
\text { Carbonized Coal } \\
\text { Briquettes }\end{array}$ & Max 20 & Maks 15 & Min 4000 & Max 1 & Min 60 \\
& $\begin{array}{l}\text { Carbonized Coal } \\
\text { Briquettes Type Coal But } \\
\text { Not Light Coal }\end{array}$ & Max 7,5 & Maks 15 & Min 5500 & Max 1 & Min 60 \\
& $\begin{array}{l}\text { Egg Type Non- } \\
\text { Carbonized Coal } \\
\text { Briquettes }\end{array}$ & Max 12 & $\begin{array}{c}\text { In accordance } \\
\text { to Original } \\
\text { Coal }\end{array}$ & Min 4400 & Max 1 & Min 65 \\
& $\begin{array}{l}\text { Wasp's Nest Type Non- } \\
\text { Carbonized Coal } \\
\text { Briquettes }\end{array}$ & Max 12 & $\begin{array}{c}\text { In accordance } \\
\text { to Original } \\
\text { Coal }\end{array}$ & Min 4400 & Max 1 & Min 10 \\
5 & Max 15 & $\begin{array}{c}\text { In accordance } \\
\text { With Raw } \\
\text { Coal Bio Briquettes }\end{array}$ & Min 4400 & Max 1 & Min 65 \\
\hline
\end{tabular}

To meet the technical requirements, the quality of the biobriquettes is analyzed based on physical and chemical tests in the laboratory. Based on Table 3 above, the details of the physical testing parameters consist of:

1) The water (moisture) contained in briquettes, consists of (Purnama, Chumaidi and Saleh, 2012): 
a. Free water (free moisture) is obtained while the process of handling coconut shells in contact with moist air and water so that the handling of free water is carried out by evaporation such as by sunlight.

b. Inherent moisture is obtained naturally during the fertilization process of coconuts on trees. The inherent moisture content was determined by heating the briquettes at a temperature of $110{ }^{\circ} \mathrm{C}$ in the oven for one hour. Based on the water content analysis performed previously in the research of biobriquettes made from the waste of Jatropha seeds, husks, jatropha peel, and coconut shell with tapioca flour adhesive, the results of the analysis showed that the highest percentage of water content in jatropha seed waste was $11.20 \%$. While the lowest water content was produced by coconut shell biobriquettes at $8 \%$. The presence of water in biobriquettes affects the time of the ignition process, such as the presence of thick smoke, and the reduce of the resulting heat (Sriharti and Salim, 2013).

2) Ask content

In general, inorganic substances are formed naturally during the process of forming raw materials (coconut shells) and during the process of making biobriquettes. The determination of ash content is carried out based on the complete combustion of biobriquettes. The percentage of ash composition consists of silica, clay, sand, and other mineral substances. Previous research on biobriquettes made from cow dung and agricultural waste (husk, straw, and coconut shells) with a composition of tapioca flour adhesive as much as $30 \%$ of the weight of the bio briquette dough obtained the lowest ash content of $7.10 \%$ (composition 1:3). While the highest ash content value is $11.75 \%$ (composition $1: 1)$. From these data, it can be seen that the more agricultural waste added to the composition, the lower the ash content of the briquettes produced will be. It is because the material from agricultural waste has undergone a carbonization process which affects the ash content that has been wasted (Sriharti and Salim, 2013).

3) The volatile matter

The volatile matter consists of flammable gases such as hydrogen $(\mathrm{H} 2)$, carbon monoxide (CO), methane ( $\mathrm{CH} 4)$, and unburned gases such as $\mathrm{CO} 2$ and $\mathrm{H} 2 \mathrm{O}$. The volatile matter is part of the biobriquette that can evaporate while the biobriquette is heated with a little oxygen or without air at a temperature of approximately 950 ${ }^{\circ} \mathrm{C}$. The existence of a high-temperature carbonization process can reduce the volatile matter content and can produce charcoal with a low volatile matter content (Moeksin, Zarwan and Alhusary, 2016).

4) The content of fixed carbon

The percentage of fixed carbon is defined as the remainder of the calculation of $100 \%$ of the total matter minus the moisture content, ash content, and volatile matter. The amount of fixed carbon is the size of the solid material in the form of residue in the combustion apparatus after the volatile matter is released. The less the water content is, the higher the fixed carbon value is (Moeksin, Zarwan and Alhusary, 2016).

5) The heating value

The heating value is the heat energy content produced by a material (thermal coal) until it burns out. The gross calorific value parameter was obtained by burning the 


\section{Vol. 2, No. 2, December 2021}

biobriquette sample in a bomb calorimeter. The percentage of net calorific value ranges from $93-97 \%$ gross value and is influenced by the inherent moisture content and hydrogen content in the briquettes (Febriana et al., 2015).

\section{METHOD}

This community service (PPM) activity was carried out in Karang Kemiri Hamlet, Belitang District, Ogan Komering Ulu Timur Regency, Southern Sumatra. This activity was conducted out for 2 weeks from 16-30 of November 2020 in the afternoon at 16.00 WIB until the evening at 20.00 WIB. This specific time was chosen to carry out the program as most of the people were farmers who work in the fields from morning to noon. The PPM implementation was attended by 15 participants and 5 team members from the program implementer. There were 3 stages included during this PPM implementation, namely:

1. Socialization

The socialization activities were carried out employing lectures and discussions by the community to introduce and convey the objectives of this PPM implementation followed by providing knowledge to the community about the use of biomass into biobriquettes that were categorized as effective and economical

2. The biobriquettes making process

The actions of making biobriquettes were directly done by the community under the instructions and accompanied by the implementing team. There were 6 (six) steps (Figure 2) making biobriquettes, namely: preparation, composing, size reduction, pressworking, and drying of biobriquettes.

3. The application of biobriquettes

The biobriquette application activities were carried out by making a furnace and burning briquettes to boil water as well as to cook Pempek Palembang by community.

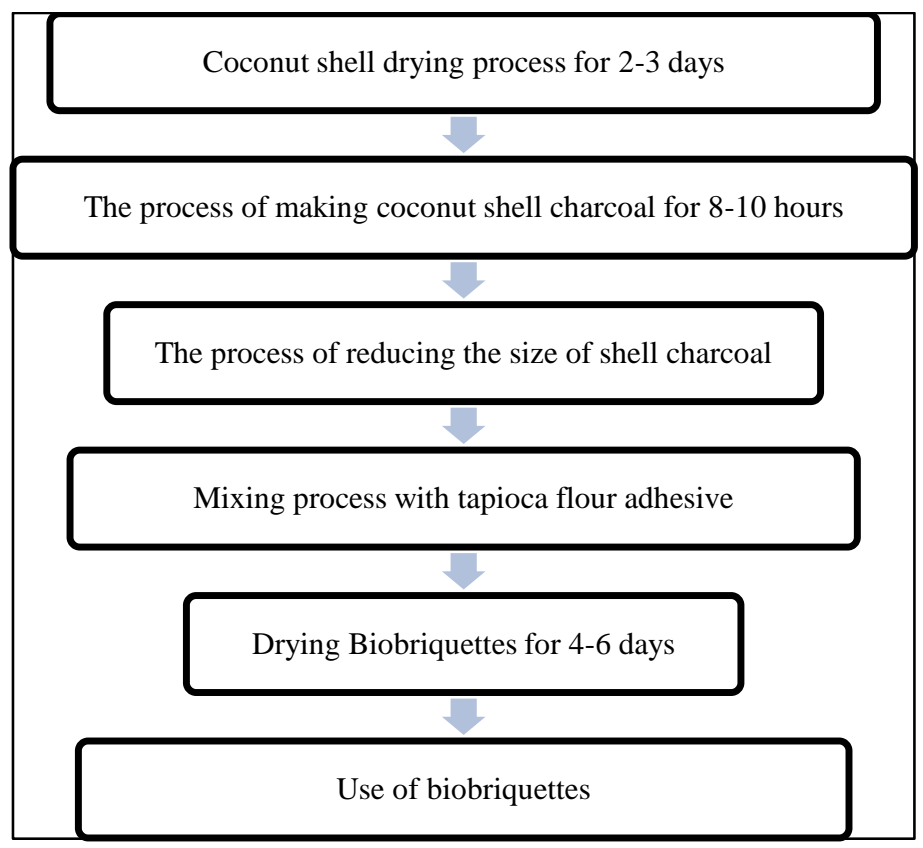

Figure 2 The flowchart of making biobriquettes 
Vol. 2, No. 2, December 2021

The materials used were coconut shell and tapioca flour, while the equipment used was a biobriquette printer from pipes, composing drums, and cameras. The work procedures carried out to support the accomplishment of this PPM were done with intensive assistance by the working team to interact directly with the community. Additionally, they also can explain in detail every process that will be carried out in the manufacture of bioriquettes.

\section{RESULTS AND DISCUSSION}

The series of results of PPM activities in Karang Kemiri village, Belitang District started from the beginning activity, namely the survey process by observing community behavior and conducting personal gatherings with each community targeted of this PPM activity. Then the core activities are carried out according to the implementation method as follows:

\section{Socialization Stage}

Socialization activities regarding biobriquettes to the community in Karang Kemiri, Belitang District were carried out simply in one of the local houses by studying the updated situation of the COVID-19 pandemic. To avoid crowds, the socialization stage was only attended by 10-15 people (Figure 3 ). The presented socialization topics consisted of background, benefits, working procedures with capital calculations to biobriquette production. The material was delivered by the working team under $45-60$ minutes followed by discussion. The socialization material also provided a simple calculation of initial capital for making biobriquettes to the public. This was done so that the community has an idea and motivation to start replacing fossil fuels with biomass fuels (biobriquettes). In detail, the simple calculations are described in Table 3.

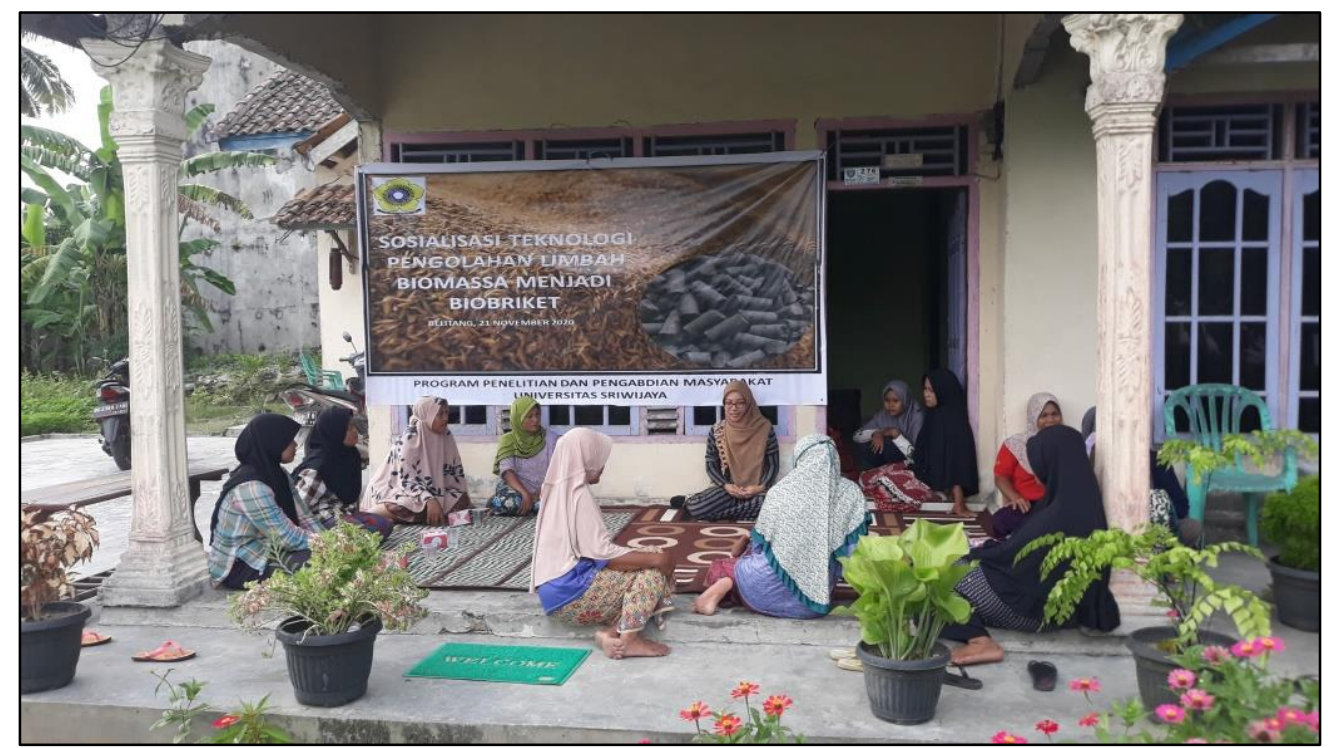

Figure 3. Outreach activities to the community 
Vol. 2, No. 2, December 2021

Table 3. Estimated cost of biobriquette production

\begin{tabular}{llcccc}
\hline No & \multicolumn{1}{c}{ Goods } & Cost & Unit & Price/Unit & Total \\
\hline 1 & Raw coconut shell & Raw Material Costs & $\mathrm{Rp} / \mathrm{kg}$ & 1.000 & $\mathrm{Rp} / \mathrm{kg}$ \\
2 & Adhesive Tapioca Flour & & 15.000 & \\
3 & Composition Drum + cover & Equipment Costs & $\mathrm{Rp} / \mathrm{unit}$ & 120.000 & \\
4 & Gunny & Rp/pcs & 50.000 & Rp. 170.000 \\
& & Cost Total & & & Rp. 186.000 \\
\hline
\end{tabular}

Based on Table 3, it can be interpreted that the total cost of making biobriquettes for beginners requires Rp. 186,000 as a startup capital which consists of two types of costs, namely the cost of materials and equipment. The cost of materials can change at any time depending on the increase in the price of goods in the market while the equipment has a useful life or depreciation occurs. Therefore, it is necessary to periodically treat the equipment so it can be used for a long time.

Based on the selling price in the market, biobriquette is normally priced at $15,000 / \mathrm{kg}$. It must be categorized as very beneficial if biobriquette becomes a business worked by the community as extra income for the people of Karang Kemiri. According to the similar community service that has been done previously, it shows that the profit obtained from the corn cob biobriquette business is Rp. 610,000/month (Sari, Maniza and Fujiaturrahman, 2018). However, the price and profit margins obtained are adjusted to each individual profit targets which want to be obtained and the community who will be the target consumers. In addition, the price of biobriquettes is also determined by the quality of the biobriquettes. The better the quality of biobriquettes is seen from the calorific value. The higher the calorific value is, the higher the price will be.

Biobriquettes might locally be used by the community at the beginning. If they got the benefit directly, then this biobriquette product might possibly be marketed among family and relatives. Inline, it is necessary to conduct an evaluation to correct the shortcomings of this biobriquette so that later the biobriquette can be sold widely in certain communities.

\section{The biobrquettes making process}

The mechanism for making biobriquettes from coconut shells is summarized in 7 (seven) step process. Each step of making biobriquettes is documented as evidence to prove this PM implementation.

\section{Step I: Preparation of coconut shell}

The process of preparing materials and equipment was carried out with the youth community of the Karang Kemiri. Later, the coconut shell was dried for 2-3 days (Figure 4) to reduce the water content in the coconut shell. In addition, it is to clean the coconut shell from impurities such as rotting coconut flesh. 
SPEKTA

Jurnal Pengabdian Kepada Masyarakat : Teknologi dan Aplikasi

Vol. 2, No. 2, December 2021

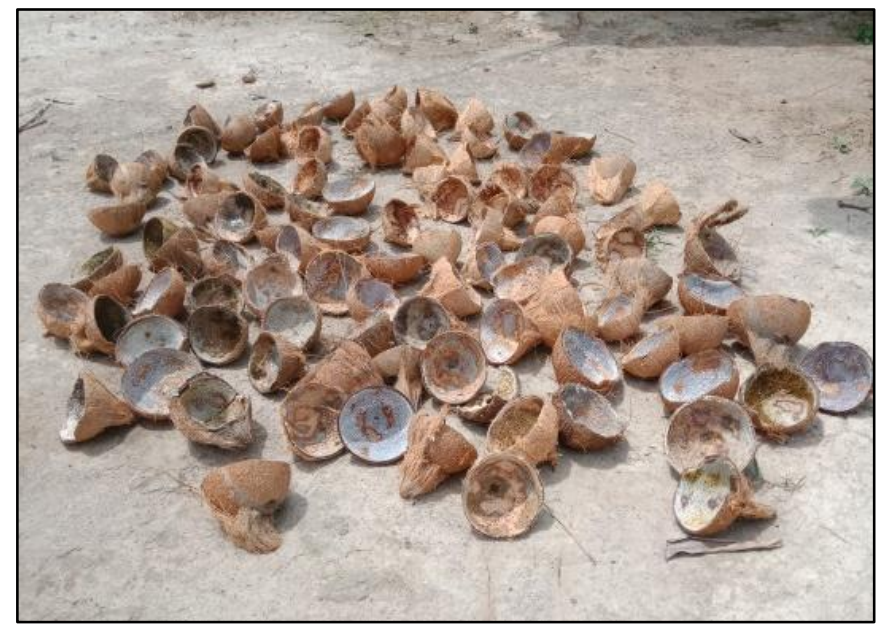

Figure 4. The coconut shell drying process

\section{Step II: The charcoal making process}

The coconut shell burning process is carried out to produce shell charcoal by the carbonization method. This process is carried out for 8-10 hours and due to the thickness and hardness of the coconut shell, it takes time to become charcoal (Figure 5). The composing is done by the pyrolysis method or burning a little oxygen so that the coconut shell does not burn completely to ashes by leaving the carbon element. According to previous research that has been carried out, it shows that the pyrolysis process is carried out to remove the elements of hydrogen $(\mathrm{H})$ and oxygen $(\mathrm{O})$ to leave the element carbon (Tumbel et al., 2019).

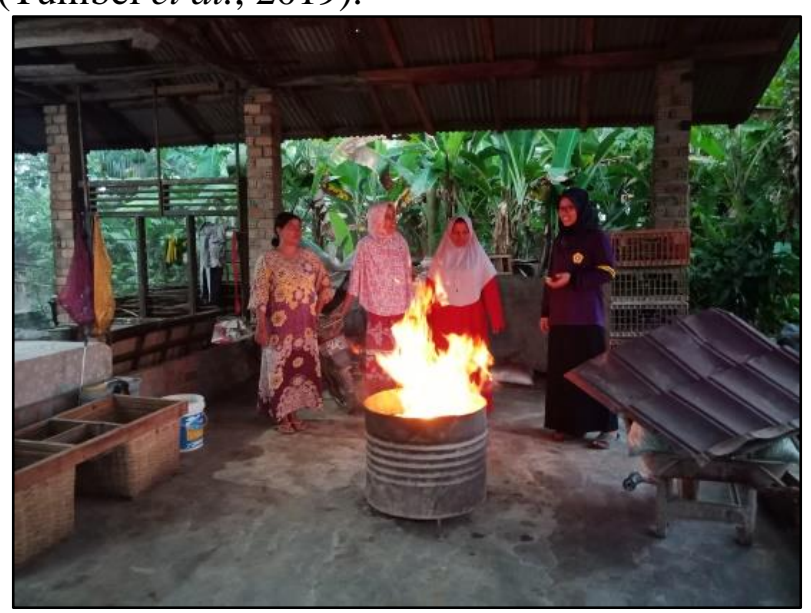

Figure 5. Documentation of coconut burning

\section{Step III: Size reduction process}

After the charcoal-making process, the next step is to reduce the size using a hammer to be approximately $3 \mathrm{~mm}$ (Figure 6). This process is carried out to help the process of gluing with tapioca flour and pressworking. An identical size would be better used as the base material for biobriquettes. It is due to the particle size for biomass briquettes should not be too large because it will cause large voids in the porosity of the biomass briquettes (Budi, 2011). 
Vol. 2, No. 2, December 2021

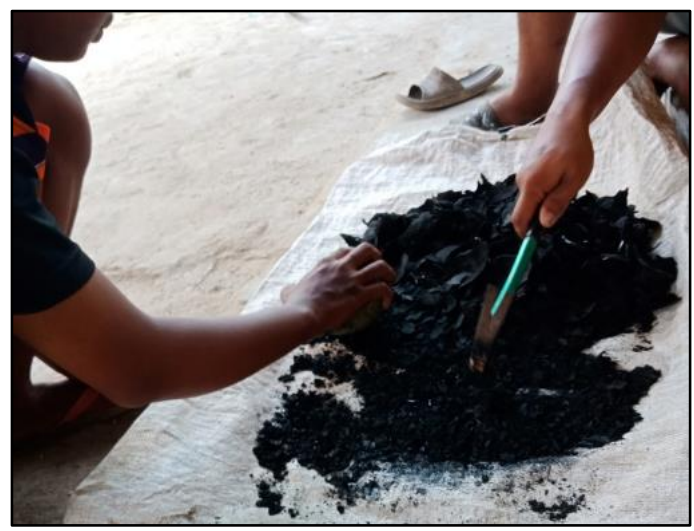

Figure 6. Documentation of the process of reducing the size with a hammer

\section{Step IV: The presswork process of biobriquettes}

After the size reduction process, the coconut shell charcoal was mixed with tapioca flour adhesive. Previously, tapioca flour was cooked with water until the texture resembled clear glue. After that, the mixing process is done in accordance with the composition ratio of 6 (charcoal): 1 (adhesive) which is then pressed using a cylindrical pipe with a diameter of 2 inches and a length of $3 \mathrm{~cm}$ (Figure 7). The composition ratio of the charcoal to the adhesive is determined based on the texture of the biobriquettes dough formed so that it is easy to print. In addition, if the composition of charcoal is more than the adhesive material it can improve the quality of biobriquettes much better (Deglas and Fransiska, 2020).

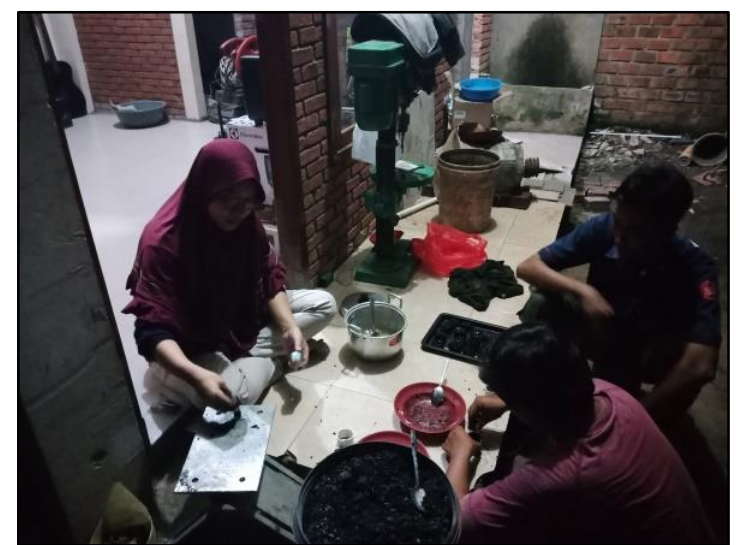

Figure 7. Biobriquettes pressworking process

\section{Step V: Biobriquettes drying process}

After the molding or presswork process, the biobriquettes were then dried by drying under the sun for 2-3 days (Figure 8). If the weather is hot then the drying process will be faster, on the contrary, if the weather is cloudy then the drying process will last longer. 
Vol. 2, No. 2, December 2021

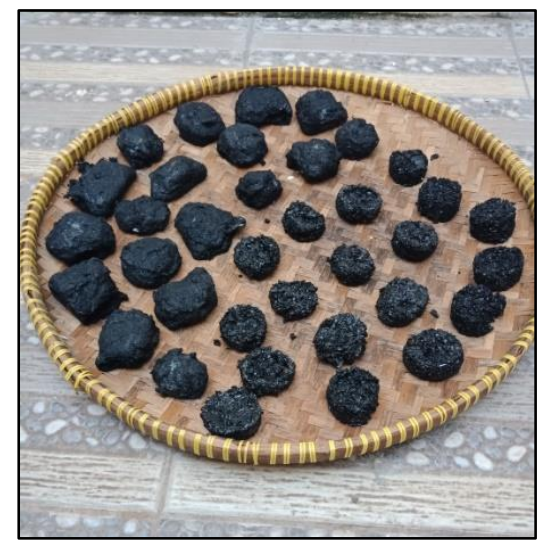

Figure 8. Biobriquettes drying process

\section{The utilization of Biobriquettes}

After the biobriquettes production process is done. The biobriquettes are then ready for utilization such used for cooking, etc. As the result, the biobriquettes are then used by the local community groups to cook, boil and fry food such as Pempek as figured below (Figure 9).

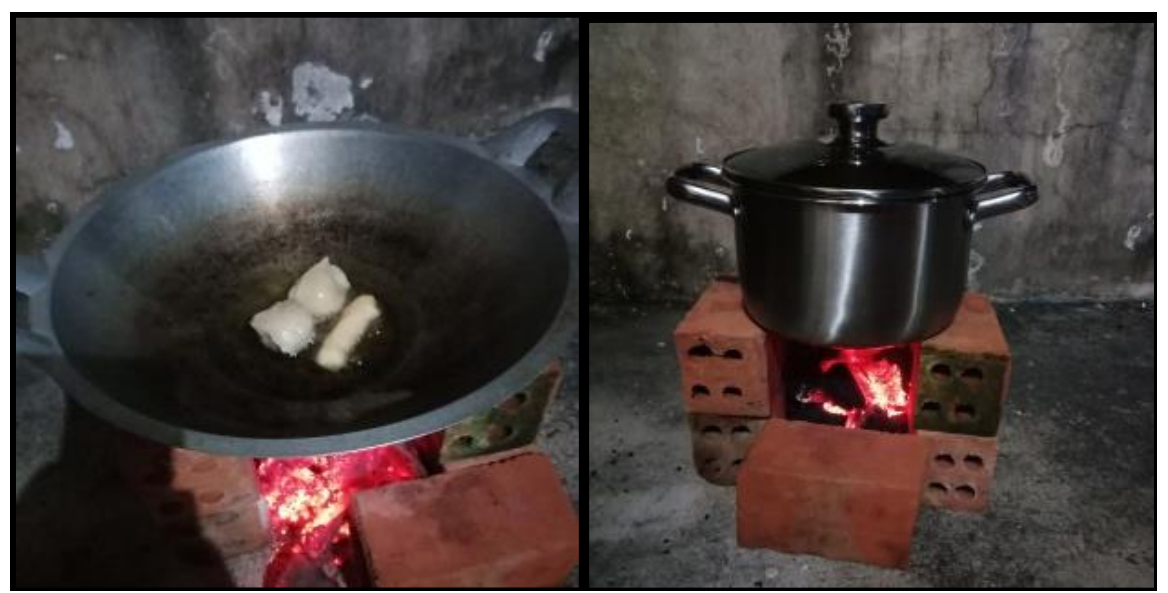

Figure 9. Cooking process by utilizing biobriquettes

\section{CONCLUSION}

Referring to the results of these all sequenced-community service (PPM) activities that have been carried out, it might possibly be concluded that the group of people in Karang Kemiri, Belitang District welcomed every stage carried out in this PPM enthusiastically. Through this community service program, the participants get a comprehensive explanation about biobriquettes, their use, and the costs needed to make biobriquettes. In addition, the community also gains additional skills to produce the biobriquettes. Besides, it is also to motivate the community to slowly reduce fossil fuels and switch to biobriquettes in their daily cooking process.

\section{ACKNOWLEDGEMENT}

On this occasion, the author would like to express gratitude to Lembaga Penelitian dan Pengabdian Masyarakat (LPPM), Sriwijaya University which has provided the funds for this Community Service (PPM) through the PNBP Grant of the year 2020. 
Vol. 2, No. 2, December 2021

\section{REFERENCES}

Badan Geologi Kementerian Energi dan Sumberdaya Mineral. 2018. Cadangan Batuara Indonesia Sebesar 26 Miliar Ton. Dikuti dari http://esdm.go.id/id/mediacenter/news-archives/cadangan-batubara-indonesia. Diakses 17 Februari 2020.

Bledzki, A. K., Mamun, A. A. and Volk, J. (2010). Barley Husk And Coconut Shell Reinforced Polypropylene Composites: The Effect Of Fibre Physical, Chemical And Surface Properties. Composites Science and Technology. 70(5), 840-846.

Budi, E. (2011). Tinjauan Proses Pembentukan dan Penggunaan Arang Tempurung Kelapa Sebagai Bahan Bakar Bahan Komponen Kandungan Sifat termal. Jurnal Penelitian Sains. 14(C), 25-29.

Deglas, W. and Fransiska, D. (2020). Analisis Perbandingan Bahan Dan Jumlah Perekat Terhadap Briket Tempurung Kelapa dan Ampas Tebu. Teknologi Pangan : Media Informasi Dan Komunikasi Ilmiah Teknologi Pertanian. 11(1), 72-78.

Febriana, I. et al. (2015). Pembuatan Briket Arang Dari Campuran Cangkang Bintaro dan Bambu Betung Menggunakan Perekat Amilum. 6 Kinetika. Vol 5, 6-12.

Labania, H. and Nismayanti, A. (2014). Studi Uji Karakteristik Fisis Briket Bioarang Sebagai Sumber Energi Alternatif. Journal of Science and Technology. 3(1), 8998.

Lubis, H. A. (2011). Uji Variasi Komposisi Bahan Pembuat Briket Kotoran Sapi dan Limbah Pertanian. Fakultas Pertanian. Fakultas Pertanian. Universitas Sumatera Utara. Medan.

Moeksin, R., Zarwan, N. and Alhusary, M. (2016). Pembuatan Biobriket Dari Campuran Tempurung Kelapa dan Cangkang Biji Karet. Jurnal Teknik Kimia. 23(3), 146-156.

Muharyani, R. et al. (2012). Pengaruh Suhu Serta Komposisi Campuran Arang Jerami Padi dan Batubara Subbituminus Pada Pembuatan Briket Bioarang. Jurnal Teknik Kimia. 23(3), 146-156.

Purnama, R. R., Chumaidi, A. and Saleh, A. (2012). Pemanfaatan Limbah Cair CPO Sebagai Perekat Pada Pembuatan Briket Dari Arang Tandan Kosong Kelapa Sawit. Jurnal Teknik Kimia. 18(3), 43-53.

Rusdianto, A. (2011). Pemanfaatan Serbuk Tempurung Kelapa Sebagai Campuran Gipsum Plafon Dengan Bahan Pengikat Lateks Akrilik. Program Pasca Sarjana. Fakultas Matematika dan Ilmu Pengetahuan Alam. Universitas Sumatera Utara. Medan.

Sari, N., Maniza, L. H. and Fujiaturrahman, D. S. (2018). PKM Kelompok Usaha Briket Melalui Pemanfaatan Limbah Bongkol Jagung Pkm Briquette Business Group Trough The Utilization Of Corn Stalk Waste. Qardhul Hasan: Media Pengabdian Kepada Masyaraka., 4(2), 102-111.

Sriharti, - and Salim, T. (2013). Pengaruh Komposisi Bahan Terhadap Karakterisasi Briket Limbah Biji Jarak Pagar (Jatropha Curcas Linn). Teknologi Indonesia. Vol 34, 40-48.

Tumbel, N. et al. (2019). Proses Pengolahan Arang Tempurung Kelapa Menggunakan Tungku Pembakaran Termodifikasi. Jurnal Penelitian Teknologi Industri. 11(2), 83-92.

Peraturan Menteri Energi dan Sumberdaya Mineral. (2006). Pedoman Pembuatan dan Pemanfaatan Briket Batubara dan Bahan Bakar Padat Berbasis Batubara. (online), (https://jdih.esdm.go.id/peraturan/permen-esdm-47-2006.pdf ). Diakses tanggal 4 Oktober 2020. 